\title{
Informal Learning of Children in The Family of Different Ethnic Parents in South Sulawesi Province
}

\author{
Arianto $^{1}$, Tuti Bahfiarti, ${ }^{2}$ Muh. Iqbal Sultan ${ }^{3}$ \\ \{arianto0773@gmail.com¹, tutibahfiarti@yahoo.com², miqsul1012@yahoo.com ${ }^{3}$ \} \\ Department of Communication Science, Faculty of Social and Political Science, Universitas \\ Hasanuddin ${ }^{1,2,3}$
}

\begin{abstract}
The purpose of this study is to describe and categorize the informal learning of children in the families of different ethnic parents in the area of South Sulawesi Province. The use of qualitative research methods is the focus of expressing meaning based on the experience of different ethnic marriage couples. This study examines the individual behavior of ethnic Balinese and Bugis/Wotu parents. In addition to in-depth interviews, data collection techniques were carried out through indirect documentation and observation techniques. Data analysis to provide a categorization of meaning inductively. The results found that the informal learning of children of different ethnic couples in the family environment. Informal learning of parents are conducted through two approaches. First, the initiative of parents in providing understanding and role models for their children. This learning is obtained from the family environment consciously or unconsciously, dialogically and participatory. Secondly, not the initiative of parents or intervention from certain parties (teachers and peers) helped provide understanding and role models for ethnic children. Conscious learning through instructional teaching in schools and peer relationships are active-dialogical and participatory.
\end{abstract}

Keywords: Informal Learning, Children, and Parents of Different Ethnicities

\section{Introduction}

In different ethnic family environments, there is a uniqueness because it brings together individuals from different cultural families in one family. Families formed through interethnic marriages have unique cultural characteristics and values. The social environment of the family can be seen from the aspect of language and the use of symbols such as clothes, religion, traditions, habits, values, and perspectives. The existence of the family is realized by every family member. Ethnic cultural characteristics are reflected in the collectivity of actions, the similarity of religion, language, clothing, values, and traditions. The process of cultural education starts with the process of cultural mixing. Informal education in the family environment starts early for cases of mixed ethnic marriages.

Informal learning of children of different ethnic couples can be grown as an achievement of their cultural understanding. The informal learning process is based on the case of Balinese ethnic children and Bugis/Wotu Local Ethnic who have a different religion, ethnicity, language and culture in Wotu District, East Luwu Regency, South Sulawesi Province. In social life, the two ethnic groups interact and engage in mixed marriages between Balinese and Bugis / Wotu locals. Children from ethnic marriages develop a search for their ethnic 
identity in family and social settings. Ethnic identity is not a fixed one but is learned through dynamic learning of self and ethnic background. Self-identity is constructed and modified when individuals are aware of their ethnicity, in a socio-cultural setting of society. For example, the case of applying effective communication strategies in each Javanese Toba Batak couple is carried out continuously throughout the marriage. The conception of effective communication is openness, empathy, positive feelings, support, and balance. Throughout the marriage, the communication that exists with the five components makes children obedient to parents even though marriages of different cultures with different characters [1].

Intensive communication of family members can form a sense of togetherness in children, so that since childhood, have known the importance of establishing relationships with family members. The sense of togetherness in the past was strengthened by family traditions. Habits make relationships more closely and fostered family relationships. Children are adopted and socialized with the values of togetherness since they were young so that in adulthood they have a caring attitude towards fellow human beings. Mainly different ethnic families and communities in their environment. The results of other studies revealed that important factors in instilling the adaptation of parents of mixed Batak-Sundanese marriages to their children, various forms of application include a balance of attention, family integrity, application of rewards, punishment and external factors. That too has a big influence on the adaptation of children [2]. Learning culture is the process of learning a whole and comprehensive unit from various manifestations that are produced and apply in each individual.

The informal learning process in ethnically diverse families through the form of inheritance of cultural traditions from children and adoption of cultural traditions of parents who do not know the culture before. Inheritance of cultural traditions is known as the process of enculturation while the adoption of cultural traditions is known as the process of acculturation. The process of acculturation and enculturation in shaping new cultures as a result of mixing two different cultures is called assimilation.

The enculturation process takes place informally in the family, the cultural community of an ethnic, or the culture of a region. The process of acculturation is carried out by parents of children, or younger people. Manners, customs, ethnic/family skills are usually passed on to the next generation through the enculturation process [3]. Learning is a civilizing process and can accelerate cultural change. For example, the learning process in the school and family environment is an informal civilizing process (acculturation process). The acculturation process is not merely a cultural transmission and cultural adoption but also a cultural change.

In the informal learning process of children of different ethnic families, the family becomes a medium for children to transform the results of observations into creative forms and principles about parental culture. Thus, through culture-based learning, children are not just imitating or receiving information delivered but children can create meaning, understanding, and meaning from the information obtained. Transformation is the key to creating meaning and developing knowledge.

The author is interested in expressing and understanding the forms of informal learning of children in families of different ethnic parents in South Sulawesi Province. Understanding forms of informal learning for children based on different cultures does not only activate children. However, it facilitates social interaction, negotiation of meaning and creation of meaning. Meaning comes from the results of social interaction and negotiation between knowledge and initial experience in gaining new information. Cultural learning, between children and parents or the external environment, such as children and teachers in the context of cultural communities. 


\section{Research Method}

Research refers to a qualitative approach. Qualitative research is a method that focuses on interpretive, constructive, naturalistic approaches to the subject. The subject of this research is children who are born, grow up, and informal learning includes multicultural attitudes and behaviors in different ethnic family lives. This type of phenomenological research to uncover and study behavior and events systematically looks for explanations for the meaning and essence of a phenomenon and is designed to gain knowledge through the experience of human life [4].

A qualitative approach expresses the meaning of one's experience. The meaning of knowledge comes from conscious experience. In phenomenology means letting things happen as they are. Cases are analyzed based on regional limitations at the level of individual and group level behavior. Restrictions in Wotu Subdistrict, East Luwu Regency are dominated by transmigrants from ethnic Balinese and Javanese. The analysis is on parents of different ethnic groups (ethnic Balinese Local Ethnic). In addition to in-depth interviews, collection techniques namely documentation and indirect observation. Next, analyze data to provide meaning categorization inductively.

Primary data sources are data obtained directly through interviews with informants. The research informant category was three intermarried couples, namely the family of Tarsisius Sutedi and Mrs. Nina, the family of Mr. Franky and Cristiana, and finally the family of Mr. Jumpa Lorentius and Mrs. Cecilia Melly. Informants were chosen purposively with consideration, having school-age children and marriage ages over 10 years and ethnic-ethnic couples who have mingled and interacted.

\section{Result and Discussion}

The process of creating meaning through the learning process of children of different ethnic families has a component of active interaction, contextual explanation, and application of knowledge, and the use of various learning resources. Informal learning of children of different ethnic parents is a form of multicultural education. The educational process without discriminating treatment due to ethnic, cultural and religious differences. Children of Balinese and Bugis/Wotu parents accept ethnic differences between their parents and have a sense of empathy, tolerance for others regardless of differences.

In everyday life, a person interacts with other people who have different cultural backgrounds. The kinship system of the children of different ethnic couples can follow the ethnicity of the male parent (father), the marriage custom depends on the agreement of the intermarried couple. The language aspect of mixed marriages can use their mother or father's language, and it is even possible to no longer use their respective ethnic languages. Informal learning of children occurs intermingling in different ethnic backgrounds, backgrounds, and cultural diversity, giving birth to multicultural families. A multicultural family is interpreted as a family in which there is a growing diversity of cultures.

Based on the results of interviews and observations show that informal learning in ethnic families between ethnic Balinese and Bugis / Wotu is done in a family environment. The aim is to change lives (especially the development of children). Children's informal learning includes: first, the initiative of parents in providing understanding and role models for their children. Children's informal learning comes from parents' everyday family environment 
consciously or unconsciously. Unconscious, irregular and unsystematic factors include: mutual respect, accepting differences and opinions of others of different ethnicities, teaching and use of Indonesian language, and learning free of stereotypes and negative prejudices in other ethnicities. The informal learning process is active and participatory. That is, during the learning process must be accustomed to intensive dialogue and participatory so that their children can develop knowledge and skills freely and independently. Participatory learning provides freedom, expression according to their interests and talents in learning. In the participatory learning model, children place themselves in an active role in cultural learning.

Second, not the initiative of parents or intervention from certain parties (teachers and peers) helped provide understanding and role models for children of ethnic parents. Learning can also be obtained consciously through instructional teaching in schools and social associations. The informal learning process is active and participatory in the school and social environment. Children of different ethnic parents participate in learning activities according to the learning steps. Such as finding problems, finding information, and reconstructing the information per cultural values (see Table 1).

Table 1. Forms of Informal Learning among Ethnic Family Children

\begin{tabular}{|c|c|c|c|c|c|c|}
\hline \multirow[t]{2}{*}{ Informant } & \multicolumn{2}{|c|}{ Ethnic } & \multicolumn{2}{|c|}{ Informal Learning } & \multicolumn{2}{|c|}{ Participation } \\
\hline & Father & Mother & $\begin{array}{l}\text { Parent } \\
\text { Initiative }\end{array}$ & $\begin{array}{c}\text { External } \\
\text { Intervention }\end{array}$ & Active & Participatory \\
\hline Informant 1 & $\begin{array}{l}\text { Balinese } \\
\text { Ethnicity }\end{array}$ & $\begin{array}{l}\text { Wotu/ } \\
\text { Bugis } \\
\text { Ethnicity }\end{array}$ & $\sqrt{ }$ & $\sqrt{ }$ & Dialogue & $\sqrt{ }$ \\
\hline Informant 2 & $\begin{array}{l}\text { Javanese } \\
\text { Ethnicity }\end{array}$ & $\begin{array}{l}\text { Bugis } \\
\text { Ethnicity }\end{array}$ & $\sqrt{ }$ & $\sqrt{ }$ & Dialogue & $\sqrt{ }$ \\
\hline Informant 3 & $\begin{array}{l}\text { Toraja } \\
\text { Ethnicity }\end{array}$ & $\begin{array}{l}\text { local } \\
\text { Ethnicity }\end{array}$ & $\sqrt{ }$ & $\sqrt{ }$ & Dialogue & $\sqrt{ }$ \\
\hline
\end{tabular}

The awareness factor of respecting, accepting differences and opinions of others is the beginning of learning to avoid stereotypes and negative prejudices in other ethnicities. Cultural and linguistic elements are mixed between intermarried couples. For example, parents can teach Balinese and Wotu/Bugis languages to their children. Language is the most important component of culture because culture transmission generally takes place. Teach their children by speaking in Indonesian with a mixture of Balinese or Bugis /Wotu languages.

Children's informal learning based on multicultural values is education that teaches children to be able to develop an attitude of tolerance and respect for diversity. The multicultural values-based learning model is an example of education that has high relevance for multicultural conditions in Indonesia. Through this, it will seek to develop children's social skills, tolerance and mutual respect for differences in the family and social environment. Children's informal learning is focused on the problem to make learning more meaningful indirectly. The learning process through children's learning has been able to solve the problem of diversity in the environment.

\section{Conclusions}


Informal learning of children from different ethnic families through the process, including: first, the initiative of parents in providing understanding and role models for their children. Children's informal learning is obtained from parents and the everyday family environment, dialogic and participatory. This process occurs unconsciously, irregularly and not systematically to understand the diversity of ethnicities in their environment.

Secondly, not the initiative of parents or intervention from certain parties (teachers and peers) helped provide learning about understanding and role models for children of different ethnic parents. Learning is obtained consciously through instructional teaching in the school and social circle of friends, actively-dialogical and participatory. Unconscious, irregular and unsystematic factors include respecting and accepting the differences and opinions of others and free learning of stereotypes and prejudices in other ethnicities. To develop children's social skills, tolerance, and respect for differences in the family and social environment.

Acknowledgments. Authors thank you to the Internal Research Grant (Basic Research Unhas 2019) Universitas Hasanuddin. Adnan as an enumerator who has helped primary data collection in East Luwu Regency, South Sulawesi. Family of research informants who have provided representative data.

\section{References}

[1] Hutajulu, L.: "Strategi Komunikasi Efektif Suami-Istri Beda Budaya dalam Mendidik Anak (Studi Kasus Pasangan Suami-Istri Suku Jawa-Batak Toba dalam Mendidik Anak di Kota Medan)," FLOW, Vol. 2, no. 8 (2016)

[2] Sonya, E. R.: "Dampak Perkawinan Campur Etnik Batak-Sunda Terhadap Integrasi Sosial," Temali: Jurnal Pembangunan Sosial, Vol. 1 no. 1, pp. 111-122 (2018)

[3] Fahrurozzi, M.: "Pembelajaran Berbasis Budaya: Model Inovasi Pembelajaran dan Implementasi Kurikulum Berbasis Kompetensi," PROSIDING (2015)

[4] Creswell, J. W.: Penelitian Kualitatif \& Desain Riset Memilih Diantara Lima Pendekatan, Yogyakarta: Pustaka Pelajar (2015) 